\title{
Classroom Management Skill Levels of Preschool Teachers ${ }^{1}$
}

Zehra Betül Yaman ${ }^{2}$
Ömer Faruk Tutkun ${ }^{3}$

\begin{abstract}
The aim of this study was to determine the classroom management skill levels of preschool teachers. Descriptive screening method was used as the research method in the study. The population of the study consisted of 705 preschool teachers in Sakarya while the study sample was comprised of 500 preschool teachers who were reached from the population. The findings obtained in the study are as follows: 1- It was found that the classroom skill levels of the pre-school teachers were slightly above the mean. 2- There was not any significant difference in the classroom management skill levels of the preschool teachers according to marital status, age, perceived income level, educational level, professional seniority years, number of students in the classroom and taking in-service training. 3- There were significant differences in the classroom management skill levels of the preschool teachers according to staff title, school location and school type. Accordingly, the contracted teachers perceived their classroom management skills higher than the permanent and substitute teachers. The teachers working in the city center perceived their classroom management skills higher than the teachers working in the district and other settlements. The teachers working in the private schools perceived their classroom management skills higher than the teachers working in the public schools.
\end{abstract}

Keywords: Preschool, Basic Education, Classroom Management, Quality of Life, Teacher

\section{INTRODUCTION}

Preschool is a time period in which a child gains skills and habits, reaches basic knowledge, learns to socialize, adapt to his/her life, comprehend solidarity, has high learning potential. Preschool period is the most important environment where the child becomes socialized and communicates with the outside world. That is why the relationship that the child establishes with his/her teacher is very important in this period (Demir 2015). The teacher who is in constant interaction with children is the only factor that determines the quality of education. Because development takes a lifetime. The first 6 years, when growth is the fastest, are the most vulnerable to the impact of the environment. For this reason, the education given to children in this first 6 years is of great importance (Nur 2012). Pre-school education supports the emotional and social development of children, and thus enables them to use their potential they have in their adulthood as efficient and productive (Özen 2008). The primary purpose of pre-school teachers and educational institutions is to prepare children for the future

1 This study has been generated from one part of postgraduate thesis supervised by second author.

2 MA, Sakarya Institute of Educational Sciences, zehrabetulyaman@gmail.com.

3 Assoc. Prof. Dr., Sakarya University, Faculty of Education Educational Sciences.

otutkun@sakarya.edu.tr 
successfully. In doing so, achieving learning outcomes is possible by providing a qualified educational environment for children. For this reason, classroom management is the primary and constant element of providing effective and qualified educational environments (Aydın 2017). The most important step of success in education and training activities is the effective management of the classroom (Yildirım 2016). The classroom is a place to face students. The change in student behavior targeted by education begins in the classroom environment. The quality of education management depends on the quality of classroom management (Semerci, 2015). The classroom is where students and teachers meet. The class has an important place in our education. (Keles, 2013). The first place where children meet the school environment is pre-school education institutions. In this period, children have difficulty in adapting to the rules and there is the possibility of undesirable behaviors. A teacher working in pre-school education institutions should be aware of the possibility of the existence of irregularity and behavioral disorders while solving problems. While investigating the reason for the behavior, it is possible to eliminate the problem with a suitable approach to the preschool child. There are various problem solving techniques in pre-school education as well as various problems. The teacher should know these strategies and methods very well, and solve the problems in their class with them. Elimination of undesirable behaviors through appropriate methods and strategies both exemplifies the student who shows this behavior and the other students, and also motivates the teacher at the same time. It also makes the education environment in the classroom more appropriate (Dal, 2016).

Preschool education institutions take place in the system as institutions supporting the family in preparing the child for social life after the family (Öztürk, 2006). The education process is not a period that can be realized by the family, the institution and the teacher alone. In this period, both the educators and the social environment in which the child is involved have great responsibilities. It must have sufficient physical facilities with appropriate pre-school educational institutions for the child to use his/her learning potential at the highest level. It is universally accepted that pre-school education years are a critical period in which children's cognitive, social, physical, emotional and language developments are completed. The fact that early childhood education is a quality process is the best possible start in the development of children. A high quality pre-school education plays an important role in the development of social and academic skills of children (Yeşilyurt 2011). The age of pre-school education is the process in which the most of the personality is shapesd and the next life is guided. In this period, no mistakes should be made since mistakes made during this period may cause the child to be adversely affected throughout his/her life. This process should not be misused by wrong practices in terms of labor (Dal, 2016).Within this scope, the classroom which is the process dimension of the school system, and the management of classroom processes are of critical importance. In this context, it can be said that the most important factor in these processes is teacher and teacher's classroom management competencies and skills. In this study, it was aimed to determine the classroom management.skill levels of preschool teachers. It is thought that the results of the study will contribute to pre-service and inservice training practices to improve the classroom management skill levels of preschool teachers, activities for the organization of preschool institutions and classes, and all stakeholders related to the parent-teacher-subject. In this context, the main research problem of this study is to determine classroom management skill levels of pre-school teachers. Within this scope, the sub-problems of the study are whether there is a difference in the classroom management skill levels of the preschool teachers according to marital status, age, perceived income level, education level, professional seniority, 
number of students in classroom, taking in-service training or not, staff title, school location and type of school.

\section{METHOD}

In the study, descriptive screening method was used as the research method. The population of the research consists of a total of 705 preschool teachers working in the center and districts of Sakarya, and the sample consists of 500 preschool teachers who were reached from these teachers. In order to determine the teachers' perceptions of classroom management skills as a data collection tool, "Classroom Management Skill Scale" developed by Denizel Güven and Cevher (2005) for pre-school teachers was used. Alpha reliability parameter of scale is .88 .

\section{FINDINGS}

In this section, it was given findings related the research problem and the sub-problems.

What are the Classroom Management Skill Levels of Preschool Teachers?

Table 1.

Mean, Standard Deviation, Minimum and Maximum Values of the Responses of the Items of Classroom Management Skill Scale

\begin{tabular}{llllll}
\hline & $\bar{x}$ & sd & Min. & Max. & Value \\
\hline Classroom Management Skill & 3.1 & .2 & 2.5 & 3.8 & Frequently \\
\hline
\end{tabular}

According to the information given in Table 1, it was found that the classroom skills levels of the preschool teachers $\left(x^{-}=3.1\right)$ were slightly above the mean.

Is There a Difference in the Classroom Management Skill Levels of Pre-school Teachers according to Marital Status?

Table 2.

Distribution of Classroom Management Skill Levels of Preschool Teachers by Marital Status

\begin{tabular}{|c|c|c|c|c|c|c|c|}
\hline & Marital Status & $\mathrm{n}$ & $\bar{x}$ & sd & $\mathrm{df}$ & $t$ & $p$ \\
\hline \multirow{2}{*}{ Classroom Management Skill } & Married & 333 & 3.07 & .21 & \multirow{2}{*}{498} & \multirow{2}{*}{1.062} & \multirow{2}{*}{.289} \\
\hline & Single & 167 & 3.05 & .22 & & & \\
\hline
\end{tabular}

When the information in Table 2 was examined, it was seen that there was no significant difference in classroom management skill levels of pre-school teachers $(t(498)=1.062, p=.289)$ according to marital status $(p>.05)$. 
Is There a Difference in the Classroom Management Skill Levels of Pre-school Teachers according to Age?

Table 3.

Distribution of Class Management Skill Levels of Preschool Teachers by Age

\begin{tabular}{|c|c|c|c|c|c|c|c|}
\hline & Age & $\mathrm{n}$ & $\bar{x}$ & sd & $\mathrm{df}$ & $F$ & $p$ \\
\hline \multirow{6}{*}{ Classroom Management Skill } & 20-24 Age & 64 & 3.03 & .18 & \multirow{6}{*}{5.494} & \multirow{6}{*}{.827} & \multirow{6}{*}{.531} \\
\hline & 25-29 Age & 145 & 3.06 & .23 & & & \\
\hline & 30-34 Age & 132 & 3.09 & .23 & & & \\
\hline & 35-39 Age & 99 & 3.05 & .19 & & & \\
\hline & 40-44 Age & 41 & 3.06 & .17 & & & \\
\hline & 45 Age and over & 19 & 3.06 & .20 & & & \\
\hline
\end{tabular}

When the information in Table 3 was examined, it was seen that there was no significant difference in the classroom management skill levels of preschool teachers $(\mathrm{F}(5.444)=.827, \mathrm{p}=.531)$ according to age $(p>$ $.05)$.

Is There a Difference in the Classroom Management Skill Levels of Pre-school Teachers according to Perceived Income Level?

Table 4.

Distribution of Classroom Management Skill Levels of Preschool Teachers According to Perceived Income Level

\begin{tabular}{lllllllll}
\hline & Perceived Income Level & $\mathrm{n}$ & $\overline{\mathrm{x}}$ & $\mathrm{sd}$ & $\mathrm{df}$ & $F$ & $p$ \\
\hline & Low & 77 & 3.04 & .23 & & & \\
\cline { 2 - 6 } Classroom Management Skill 2.497 & 1.385 & .251 \\
\cline { 2 - 6 } & Middle & 396 & 3.06 & .21 & & & \\
\cline { 2 - 6 } & High & 27 & 3.12 & .18 & & & & \\
\hline
\end{tabular}

When the information in Table 4 was examined, it was seen that there was no significant difference in the classroom management skill levels of preschool teachers $\left(F_{(2.497)}=1.385, p=.251\right)$ according to perceived income level $(p>.05)$.

Is There a Difference in the Classroom Management Skill Levels of Pre-school Teachers according to Education Level?

Table 5.

Distribution of Classroom Management Skill Levels of Preschool Teachers by Education Level

\begin{tabular}{llllllll}
\hline & Education Level & $\mathrm{n}$ & $\bar{x}$ & $\mathrm{sd}$ & $\mathrm{df}$ & $F$ & $p$ \\
\hline Classroom Management Skill & Associate's degree & 55 & 3.10 & .21 & 2.498 & .798 & .451 \\
\hline
\end{tabular}




\begin{tabular}{llll} 
Undergraduate Degree & 418 & 3.06 & .21 \\
\hline Master Degree & 27 & 3.06 & .16
\end{tabular}

When the information in Table 5 was examined, it was seen that there was no significant difference in the classroom management skill levels of preschool teachers $\left(F_{(2.497)}=.798, p=.451\right)$ according to education level $(p>.05)$.

Is There a Difference in the Classroom Management Skill Levels of Pre-school Teachers according to Professional Seniority?

Table 6.

Distribution of Classroom Management Skill Levels of Preschool Teachers According to Professional Seniority Year

\begin{tabular}{|c|c|c|c|c|c|c|c|}
\hline & Professional Seniority Year & $\mathrm{n}$ & $\bar{x}$ & sd & $\mathrm{df}$ & $F$ & $p$ \\
\hline \multirow{6}{*}{$\begin{array}{l}\text { Classroom Management } \\
\text { Skill }\end{array}$} & 1 Year and less & 42 & 3.02 & .20 & \multirow{6}{*}{5.497} & \multirow{6}{*}{.948} & \multirow{6}{*}{.449} \\
\hline & 2-5 Year & 116 & 3.05 & .22 & & & \\
\hline & 6-10 Year & 190 & 3.06 & .21 & & & \\
\hline & 11-15 Year & 89 & 3.10 & .21 & & & \\
\hline & 16-20 Year & 38 & 3.06 & .19 & & & \\
\hline & 21 Year and over & 25 & 3.06 & .21 & & & \\
\hline
\end{tabular}

When the information in Table 6 was examined, it was seen that there was no significant difference in the classroom management skill levels of preschool teachers $\left(F_{(5.494)}=.948, p=.449\right)$ according to professional seniority $(p>.05)$.

Is There a Difference in the Classroom Management Skill Levels of Pre-school Teachers according to Staff Title?

Table 7.

Distribution of Classroom Management Skill Levels of Preschool Teachers According to Staff Title

\begin{tabular}{|c|c|c|c|c|c|c|c|}
\hline & Staff Title & $\mathrm{n}$ & $\bar{x}$ & sd & $\mathrm{df}$ & $F$ & $p$ \\
\hline \multirow{3}{*}{ Classroom Management Skill } & Permanent Teacher & 350 & 3.05 & .21 & \multirow{3}{*}{2.498} & \multirow{3}{*}{4.256} & \multirow{3}{*}{.015} \\
\hline & Substitute Teacher & 100 & 3.06 & .20 & & & \\
\hline & Contract Teacher & 50 & 3.14 & .20 & & & \\
\hline
\end{tabular}

When the information in Table 7 was examined, it was seen that there was a significant difference in the classroom management skill levels of preschool teachers $(F(2.497)=4.256, p=.015)$ according to staff title $(p<.05)$. According to this, it was seen that the contract teachers perceived their classroom management skills as higher compared to the permanent and substitute teachers. 
Is There a Difference in the Classroom Management Skill Levels of Pre-school Teachers according to Number of Students in Classroom?

Table 8.

Distribution of Classroom Management Skill Levels of Preschool Teachers by Number of Students in Classroom

\begin{tabular}{|c|c|c|c|c|c|c|c|}
\hline & Number of Students in Classroom & $\mathrm{n}$ & $\bar{x}$ & sd & $\mathrm{df}$ & $F$ & $p$ \\
\hline \multirow{4}{*}{ Classroom Management Skill } & 10-15 Students & 148 & 3.06 & .22 & \multirow{4}{*}{3.496} & \multirow{4}{*}{1.877} & \multirow{4}{*}{.132} \\
\hline & 16-20 Students & 194 & 3.04 & .20 & & & \\
\hline & 21-25 Students & 134 & 3.09 & .23 & & & \\
\hline & 26 Students and over & 24 & 3.10 & .19 & & & \\
\hline
\end{tabular}

When the information in Table 8 was examined, it was seen that there was no significant difference in the classroom management skill levels of preschool teachers $\left(F_{(3.496)}=1.877, p=.132\right)$ according to number of students in classroom $(p>.05)$.

Is There a Difference in the Classroom Management Skill Levels of Pre-school Teachers according to Taking In-service Training or Not?

Table 9.

Distribution of Class Management Skill Levels of Pre-School Teachers by Taking In-service Training or not

\begin{tabular}{|c|c|c|c|c|c|c|c|}
\hline & In-service Training & $\mathrm{n}$ & $\overline{\mathrm{x}}$ & sd & $\mathrm{df}$ & $t$ & $p$ \\
\hline \multirow{2}{*}{ Classroom Management Skill } & Taken & 382 & 3.07 & .21 & \multirow{2}{*}{498} & \multirow{2}{*}{1.563} & \multirow{2}{*}{.119} \\
\hline & Not Taken & 118 & 3.04 & .20 & & & \\
\hline
\end{tabular}

When the information in Table 9 was examined, it was seen that there was no significant difference in the classroom management skill levels of preschool teachers $\left(t_{(498)}=1.563, p=.119\right)$ according to taking in-service training or not $(p>.05)$.

Is There a Difference in the Classroom Management Skill Levels of Pre-school Teachers according to School Location?

Table 10.

Distribution of Classroom Management Skill Levels of Pre-School Teachers by School Location

\begin{tabular}{llllllll}
\hline & School Location & $\mathrm{n}$ & $\bar{x}$ & $\mathrm{sd}$ & $\mathrm{df}$ & $F$ & $p$ \\
\hline & Province & 191 & 3.09 & .21 & & & \\
Classroom Management Skill & District & 277 & 3.05 & .21 & 2.498 & 3.462 & .032 \\
& Other & 32 & 3.03 & .19 & & & \\
\hline
\end{tabular}

When the information in Table 10 was examined, it was seen that there was a significant difference in the classroom management skill levels of preschool teachers $\left(F_{(2.497)}=3.462, p=.032\right)$ according to school 
location $(p<.05)$. According to this, it was seen that the teachers working in the city center perceived their classroom management skills as higher than the teachers working in the district and other settlements.

Is There a Difference in the Classroom Management Skill Levels of Pre-school Teachers according to School Type?

Table 11.

Distribution of Class Management Skill Levels of Preschool Teachers by School Type

\begin{tabular}{|c|c|c|c|c|c|c|c|}
\hline & School Type & $\mathrm{n}$ & $\bar{x}$ & sd & df & $t$ & $p$ \\
\hline \multirow{3}{*}{ Classroom Management Skill } & State School & 456 & 3.05 & .21 & \multirow{3}{*}{498} & \multirow{3}{*}{-2.809} & \multirow{3}{*}{.005} \\
\hline & & & & & & & \\
\hline & Private School & 44 & 3.15 & .18 & & & \\
\hline
\end{tabular}

When the information in Table 11 was examined, it was seen that there was a significant difference in the classroom management skill levels of preschool teachers $\left(t_{(498)}=-2.809, p=.005\right)$ according to school type $(p<.05)$. According to this, the teachers working in private schools perceived classroom management skills as higher than the teachers working in public schools.

\section{DISCUSSION}

In this study, in which it was aimed to determine the classroom skill levels of preschool teachers, it was found that the classroom management skill levels of preschool teachers were slightly above the mean. When the studies in the literature related to this result were examined, it was seen that In the research conducted by Küsmüş (2018), the classroom management skills of pre-school teachers were found to be high. In the study of Adigüzel (2016), it was found that preschool teachers working in the city center and districts of Samsun had adequate classroom management skills. In the study conducted with the preschool teachers working in the public and private preschool institutions of the Ministry of National Education in the Küçükçekmece district of İstanbul, Yıldız (2018) revealed that the pre-school teachers had high classroom management skills. In the research conducted by Karatekin (2018), the classroom management skills of pre-school teachers were found to be good.

According to the study results, it was found that there was no significant difference in the classroom management skills of married and single preschool teachers. There are studies that support this study in the literature. In the studies conducted by Adigüzel (2016), Semerci (2015) and İpek (2015), it was determined that classroom management skills did not differ significantly according to marital status. On the other hand, according to the results of the study, there was no significant difference in the classroom management skills of preschool teachers according to age. Among the studies supporting the present study in the literature, the study conducted by Yildiz (2018) on the relationship between the burnout and classroom management skills levels of the pre-school teachers revealed that there was no significant difference in the classroom management skills of pre-school teachers according to age. However, in the study conducted by Semerci (2015) on the relationship between preschool teachers' classroom 
management skills, self-efficacy perceptions and professional motivations, it was found that the teachers aged 25 years or under had higher class management skills than the older teachers.

In the study, there was no significant difference in the classroom management skills of pre-school teachers according to perceived income level. In Adıgüzel's (2016) study, it was also determined that the classroom management skills did not show a significant difference according to satisfaction for income and income level. According to the another result of the study, the classroom management skills of the preschool teachers did not differ significantly according to education level. This finding coincided with the results of the study made by Yildiz (2018). According to the results of Yildiz's (2018) study, there was no significant difference in classroom management skills according to educational level. However, in the study conducted by Semerci (2015), it was found that the teachers who had vocational high school grdauation and associated degree had higher class management skills than the teachers who had undergraduate and graduate degrees.

In the study, the classroom management skills of the preschool teachers did not show a significant difference according to their seniority. This result was ssupported by the results of the study by Adıgüzel (2016) and İpek (2015). In these studies, it was also determined that classroom management skills did not show a significant difference compared to the year of seniority. On the other hand, in a study by Semerci (2015), it was found that the teachers who had been in the teaching profession for more than 16 years had higher class management skills than the teachers who had been working for a shorter time.

In the study, according to the number of students in the classroom, there was no significant difference between the classroom management skills of the preschool teachers. This result coincided with the study results of Adıgüzel (2016). However, in the study of Semerci (2015), it was determined that the teachers of the low number of students in the classroom had higher class management skills compared to the teachers of the high number of students in the classroom.

In the sudy, it was determined that the level of classroom management skills of pre-school teachers did not show any significant difference in terms of taking in-service training or not. In Daştan's (2016) study, it was found that the classroom management skills of the teachers who received in-service training were higher than those who did not received in-service training. According to the another result of this study, it was determined that the contracted teachers perceived their class management skills as higher than the the skills of the permanent and substitute teachers. However, in the study of Adıgüzel (2016), it was determined that the levels of classroom management skills did not differ betweenthe teachers working as permanent and substitute teachers. In the study, it was determined that teachers working in the city center perceived their class management skills as higher than the teachers working in the district and other settlements. However, in the study conducted by Ipek (2015), it was determined that classroom management skills did not differ significantly according to the location of the school. On the other hand, it was determined in this study that the teachers working in the private schools perceived their classroom management skills as higher than the teachers working in the public schools. This result was supported by the research results of Semerci (2015).

\section{RECOMMENDATIONS}


Based on the results of the study, the recommendations for future research are as follows: 1- Teachers working in districts and other settlements should be provided with an incentive system such as salary, seniority and additional service points, and training programs should be organized to increase their class management competencies. 2- The physical conditions and quality of service in public schools should be brought to the level of private schools. 3- This research should be done on the preschool teachers across Turkey, thus, classroom management skill levels of preschool teachers should be determined and training programs should be arranged according to the results to be obtained. 4- Parentteacher-school cooperation should be given in order to provide parents to increase their competencies and to gain awareness in the subjects of cooperation with schools and teachers, sustaining what to gain in school at home, and supporting school learning.

\section{REFERENCES}

Adıgüzel, İ. (2016). Okul öncesi öğretmenlerinin sınıf yönetimi becerileri ile tükenmişlik düzeyleri arasındaki ilişki (Yayınlanmamış yüksek lisans tezi). Recep Tayyip Erdoğan Üniversitesi, Sosyal Bilimler Enstitüsü.

Aydın, D. (2017). Okul öncesi öğretmenlerinin sını yönetimi becerilerinin öğretmenlik stilleri üzerindeki etkisi (Yayınlanmamış yüksek lisans tezi). Ege Üniversitesi, Sosyal Bilimler Enstitüsü.

Dal, M. (2016). Okul öncesi öğretmenlerinin öğrencilerin istenmeyen davranışlarıyla baş etmede kullandıkları sınıf yönetimi stratejileri(Yayınlanmamış yüksek lisans tezi). Atatürk Üniversitesi, Eğitim Bilimleri Enstitüsü.

Daştan, Ş. (2016). Okul öncesi öğretmenlerinin öz-yeterlik düzeyleri ile üstün yeteneklilerin eğitimine yönelik tutumların karşılaştırılması (Yayınlanmamış yüksek lisans tezi). Gazi Üniversitesi, Eğitim Bilimleri Enstitüsü.

Demir, T. (2015). Okul öncesi öğretmenlerinin öz-yeterlik algılarının ve sınıf yönetimi stratejilerinin çocuköğretmen ilişkileri üzerinde etkileri (Yayınlanmamış yüksek lisans tezi). Ege Üniversitesi, Sosyal Bilimler Enstitüsü.

Denizel Güven, E., \& Cevher, F. N. (2005). Okul öncesi öğretmenlerinin sınıf yönetimi becerilerinin çeşitli değişkenler açısından incelenmesi. Pamukkale Üniversitesi Eğitim Fakültesi Dergisi, 18(2), 122.

İpek, S. (2015). Temel eğitimde görev yapan öğretmenlerin sınıf yönetimi öz-yeterlik inançları ve mesleki tutumları (Rize ili örneği) (Yayınlanmamış yüksek lisans tezi). Avrasya Üniversitesi, Sosyal Bilimler Enstitüsü.

Karatekin, K. N. Ç. (2018). Okul öncesi öğretmenlerinin iletişim becerileri ile sınıf yönetimi becerileri arasındaki ilişkinin incelenmesi (Yayınlanmamış yüksek lisans tezi). Marmara Üniversitesi, Eğitim Bilimleri Enstitüsü.

Keleş, O. (2013). Okul öncesi öğretmen adaylarının ve okul öncesi öğretmenlerinin sınıf yönetimine ilişkin tutum ve inançlarının incelenme (Yayınlanmamış yüksek lisans tezi). Çukurova Üniversitesi. 
Küsmüş, G. İ. (2018). Okul öncesi öğretmenlerinin sınf yönetimi becerileri ile mesleki profesyonellikleri arasındaki ilişkinin incelenmesi (Yayınlanmamış yüksek lisans tezi). Marmara Üniversitesi, Eğitim Bilimleri Enstitüsü.

Nur, İ. (2012). Anaokullarında örgüt iklimi ile öğretmenlerin sınıf yönetimi becerileri arasındaki ilişkinin incelenmesi (Yayınlanmamış yüksek lisans tezi). İnönü Üniversitesi, Eğitim Bilimleri Enstitüsü.

Özen, Ş. (2008). Okul öncesi eğitim ve aile: Anne ve babaların okul öncesi eğitimden beklentileri (Yayınlanmamış yüksek lisans tezi). Kafkas Üniversitesi, Sosyal Bilimler Enstitüsü.

Öztürk, A. (2006). Okul öncesi öğretmenlerinin duygusal zekâ yetenekleri iş doyumları ve tükenmişlik düzeylerinin bazı değişkenler açısından karşılaştırmalı olarak incelenmesi (Yayınlanmamış yüksek lisans tezi). Selçuk Üniversitesi, Sosyal Bilimler Enstitüsü.

Semerci, D. (2015). Okul öncesi öğretmenlerinin sınıf yönetimi becerileri, öz yeterlik algıları ve mesleki motivasyonları arasındaki ilişkinin incelenmesi (Yayınlanmamış yüksek lisans tezi). Marmara Üniversitesi, Eğitim Bilimleri Enstitüsü.

Yeşilyurt, Z. C. (2011). Çocukları anaokuluna devam eden ebeveynlerin okul öncesi eğitim kurumlarından beklentileri ve kurumların bu beklentileri karşılama durumları (Yayınlanmamış yüksek lisans tezi). Pamukkale Üniversitesi, Sosyal Bilimler Enstitüsü.

Yıldırım, Ö. (2016). Okul öncesi öğretmenlerinin iş doyumu ile sınıf yönetimi becerileri arasındaki ilişki (Yayınlanmamış yüksek lisans tezi). İstanbul Üniversitesi, Eğitim Bilimleri Enstitüsü.

Yıldız, M. (2018). Okul öncesi öğretmenlerinin tükenmişlik düzeylerinin sınıf yönetimi becerileri ile ilişkisi (Yayınlanmamış yüksek lisans tezi). İstanbul Aydın Üniversitesi Ve Yıldız Teknik Üniversitesi, Sosyal Bilimler Enstitüsü. 